\title{
Promoting the correct production of English sounds in extensive reading-circle classes: Explicit vs. implicit pronunciation training
}

\author{
İlyas YAKUT $\mathrm{a}^{*}$
}

a Zonguldak Bülent Ecevit University, Department of English Language and Literature, Zonguldak 67020, Turkey Received 19 August 2019 | Received in revised form 20 November 2019 | Accepted 7 December 2019

APA Citation:

Yakut, İ. (2020). Promoting the correct production of English sounds in extensive reading-circle classes: Explicit vs. implicit pronunciation training. Eurasian Journal of Applied Linguistics, 6(1), 101-118.

Doi: 10.32601/ejal.710224

\begin{abstract}
Correct pronunciation of English words is of vital significance for mutual intelligibility in the EFL context. Despite its prominence in L2 learning, teachers of English cannot decide whether and how to implement pronunciation practice into their teaching practices. For this reason, pronunciation training is widely neglected in language classes or learners of English might learn incorrect pronunciation of segmental units causing fossilization in L2 setting. The importance of pronunciation training has been highlighted in the related literature. Keeping this fact in mind, this study aims to explore whether explicit pronunciation instruction has a superiority over implicit instruction in extensive reading classes. To reach this purpose, two groups of successive B1-level Intensive English Program (IEP) students were chosen through convenience sampling technique. Before training, both groups were given a pre-test of segmental unit pronunciation consisting of the most frequented words in the book used for the extensive reading classes at $\mathrm{B} 1$ level. Then the participants in the control group received implicit pronunciation training in which the language instructor did not directly focus on phonemic properties of English sounds. However, explicit pronunciation training was implemented into the teaching practices in the experimental group. The teaching period lasted eight weeks, and following this period both groups were given a post-test to unravel the level of improvement in each group. The results of this study revealed that explicit pronunciation training is more advantageous for B1 level students than the implicit one due to various reasons.
\end{abstract}

(C) 2020 EJAL \& the Authors. Published by Eurasian Journal of Applied Linguistics (EJAL). This is an open-access article distributed under the terms and conditions of the Creative Commons Attribution license (CC BY-NC-ND) (http://creativecommons.org/licenses/by-nc-nd/4.0/).

Keywords: explicit vs. implicit instruction; extensive reading; segmental pronunciation; teaching pronunciation

\section{Introduction}

Throughout the history of English language teaching whether and how to teach pronunciation to learners of a specific language have been discussed by linguists and language instructors (Fraser, 1999; Pourhosein Gilakjani, 2012; Saka, 2015). As could be inferred from Lightbrown and Spada (2013), Larsen-Freeman and Anderson (2011) and Richards and Rodgers (2006), depending on the purposes of the language training

\footnotetext{
* Corresponding author. Tel.: +0-372-291-1877

E-mail address: yakutilyas@gmail.com http://dx.doi.org/10.32601/ejal.710224
} 
and the method adopted, the significance of pronunciation training and the way the teacher approaches teaching pronunciation change. When the Grammar Translation Method was popular, pronunciation training was not given importance since the aim was to improve the ability of reading, writing and translation. However, pronunciation training gained importance with the emergence of the Direct Method and the Audiolingual Method, and it was taught through imitation, corrective feedback and reinforcement (Demirezen, 2010). Especially in the Audiolingual Method, the aim was to reach perfect pronunciation through activities based on listening and repetition. For this reason, an intuitive-imitative approach (CelceMurcia, Brinton \& Goodwin, 1996) based on activities aiming to foster rote learning through listening and repeating specific texts was adopted (Richards \& Rodgers, 2006). Even though pronunciation teaching lost its prominence during the 1960s (Preston, 1981), the emergence of the Silent Way (Gattegno, 1963) sparkled the pronunciation training in the classroom again by using the Fidel chart (sound-color chart).

Despite the previous methods, pronunciation training has become an integrated part of language teaching with the introduction of the communicative competence by Hymes (1972). The communicative competence and communicative language teaching give importance to intelligibility and meaningful interaction. Thus, appropriate pronunciation in the target language is promoted by the language teachers who adopt communicative approaches in their classes since mutual intelligibility in the spoken discourse is directly affected by the level of in/correct pronunciation of the words. In addition to segmental elements of pronunciation, the supra-segmental elements such as rhythm and stress are taught in language classes where communicative language teaching is adopted.

However, as pronunciation training is integrated into the whole language teaching process, it has been observed that pronunciation sections of the curricula have been neglected by language teachers (Underhill, 2005; Hişmanoğlu, 2006). In addition, due to the idea of English as a Lingua Franca (Seidlhofer, 2005; Jenkins, 2007), it has been highlighted by many scholars (Jenkins, 2000; Derwing \& Munro, 2008; Walker, 2010; Brinton, 2017) that the way a word is pronounced does not play a crucial role as long as interlocutors could mutually comprehend the meaning that they try to convey, and this could be provided through negotiation for meaning.

Even though teaching pronunciation might be neglected by some language instructors, Fraser (1999) states that we need not to discuss whether pronunciation training should be integrated into the language teaching process, but how to teach pronunciation should be the central focus. The relationship between teaching techniques of pronunciation and mastering appropriate pronunciation of English words in EFL/ESL contexts has been a debate among the researchers as some studies reveal the superiority of explicit pronunciation training over the implicit one (Derwing \& Munro, 2005; Venkatagiri \& Levis, 2007; Couper, 2011; Saito, 2011; Sturm, 2013) while some others (Morley, 1991; Flege, Yeni-Komshiam, \& Liu, 1999; Papachristou, 
2011; Kissling, 2013; Chan \& Leung, 2014) indicate that explicit instruction does not positively affect the performance of learners' pronunciation.

\section{Review of Literature}

\subsection{Implicit and explicit pronunciation training}

Spoken language consists of verbal and non-verbal components of the linguistic features. The production of appropriate sounds is noteworthy since it might affect the smoothness of the spoken interaction. According to Darcy (2018), along with lexis and structure, phonetics and phonology of a language are at the heart of the linguistic components of that language. The sound system of a language and the other elements (e.g. lexis, structure, pragmatics etc.) are interwoven. For this reason, pronunciation training should be included in the language teaching curriculum to be able to upskill learners in the target language (TL). Contrary to this fact, Derwing and Rossiter (2002) highlight that

Although researchers and teacher educators have called for more attention to the incorporation of pronunciation instruction in language classes, with an emphasis on prosodic elements, the L2 learners' responses suggest that they are either not getting instruction or, if they are, they are not benefiting from it (p. 161).

The statement of the abovementioned researchers indicates that there is a mismatch between the requirements of effective language teaching and the implementation of pronunciation training strategies in the classroom settings. In the same line, Fraser (2006) points out that teachers of English might neglect pronunciation due to not having the necessary training or not having confidence to teach sounds and sound patterns of the TL. Despite this reality, Fraser (2000) puts forward the claim that language instructors should not ignore phonetical and phonological properties of language. Yet, they need to discuss how to teach accurate pronunciation of sounds in a specific language to provide mutual intelligibility in spoken discourse. As pronunciation training is a must in language classes, there is a growing body of literature in the field aiming to explore whether explicit or implicit teaching of pronunciation is more beneficial for language learners.

Saito (2011) investigated the effects of explicit phonetic instruction on Japanese learners of English. To investigate the relationship between formal pronunciation training and appropriate pronunciation, the participants in the experimental group received explicit instruction while those who were assigned to the control group did not receive direct pronunciation training. Using pre-test and post-test, he found that those who received explicit instruction were more successful in communicative tasks. Similarly, Couper (2011) presented an investigation of the superiority of explicit instruction in the pronunciation of syllable codas.

In addition, Silveria (2011) focused on the role of explicit pronunciation instruction in the discrimination of English syllabic patterns. The results of the quasiexperimental study exhibited that participants in the experimental group came along 
better in the post-test after receiving explicit instruction. Furthermore, Khanbeiki and Abdolmanafi-Rokni (2015) revealed the advantage of explicit pronunciation training in the correct pronunciation of English consonant clusters among Iranian learners of English. Contrarily, Papachristou (2011) investigated the relationship between explicit versus implicit pronunciation training and the production of English vowels. Conducting the research with young adult Greek learners of English, the participants were divided into two groups. In the first group, students received explicit instruction through a variety of pronunciation activities. On the other hand, students in the second group received implicit instruction and only recast was used and the overall findings revealed that students who received implicit instruction produced more native-like vowel sounds.

Derwing and Munro (2005) focused on the effectiveness of explicit instruction on mutual intelligibility and comprehensibility. Designing their study as a quasiexperimental one, they found that explicit teaching of pronunciation improved mutual intelligibility and comprehensibility of the learners. They concluded that when appropriate instruction is not given, foreign language accent might reduce intelligibility in both native-nonnative and nonnative-nonnative interactions.

Zhang and Yin (2009) focused on the most frequented pronunciation errors of learners of English. The data were collected through read-aloud sessions in academic reading classes and the results showed that the most frequent errors were related to misperceived sounds, misperception of morphological changes, adding and missing sounds, misperception of unstressed elements, paraphrase and assimilation errors.

\subsection{Pronunciation in Turkish EFL Setting}

Similar to other EFL learners, correct pronunciation of some English words is problematic for Turkish learners of English. Thus, scholars have focused on different aspects of pronunciation issues among Turkish EFL learners.

Demirezen (2005) investigated the problematic sounds /o/, /ow/ and /ou/produced by Turkish teacher trainees of English and suggested that these problematic sounds might be correctly pronounced through audio-articulation method which prioritizes to curing fossilized pronunciation mistakes through raising awareness by focused listening activities and speaking exercises. In two different studies, Demirezen (2003, 2010) highlights that the method works best when listening texts are created via corpus, minimal pairs, minimal sentences and sensational clues. Since the purpose of this method is to cure fossilized mistakes, he suggests that the problematic sounds for Turkish EFL learners need to be specified and then a corpus for the listening texts should be designed. According to him, the most problematic sounds for Turkish EFL

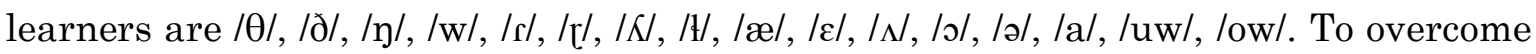
problematic sounds, he suggests that the appropriate articulation of these core sounds needs to be taught through corpus based audio-articulation method in EFL setting.

Similarly, Hişmanoğlu (2007) conducted research to explore the incorrect pronunciation of /ov/ and / $/$ / by Turkish EFL learners and suggests a possible solution 
to remedy this fossilization. According to his method, a corpus including the problematic sounds should be created. He also supports the idea of modeling the correct pronunciation though explicit introduction of rules, listen-repeat activities and minimal pairs. Such an explicit way of pronunciation training might help learners correct their fossilized pronunciation errors. Even though Hişmanoğlu explored the pronunciation of $/ \mathrm{ov} /$ and $/ \mathrm{s} / /$ in that study, he states that in addition to these sounds,

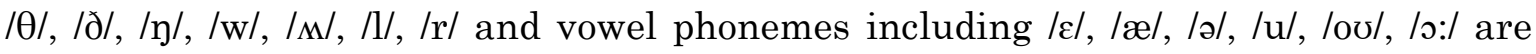
problematic for Turkish EFL learners.

In another study, Türker (2010) explored the pronunciation mistakes of Turkish secondary school students. To collect data, he worked with 733 high school students and the participants were asked to read two sentences. The voices were recorded and transcribed by the researcher. According to the results, the most problematic sounds for Turkish EFL learners are / $/ \theta /, / \mathrm{d} /, / \mathrm{y} /, / \mathrm{w} /$ consonants /3:/, /ə/, / //, /p/, / $/ \mathrm{h}$, /a/ vowels and /əv/, / / $/$ /, /ıə/, /eə/, /av/. Additionally, the author indicated that most of the pronunciation errors occur due to following the example of the teachers. Thus, it is highlighted by him that modeling is an essential factor in pronunciation training.

Similar to the studies mentioned above, Bardakçı (2015) investigated the pronunciation problems of the pre-service English language teachers. The participants were introduced to the International Phonetics Alphabet, and they received transcription reading education. Then, the participants were asked to prepare oral presentations about the topics they were interested in. Their presentations were video-recorded. After that both the researcher and the presenters checked the video recordings to find the mispronounced words. They did not focus on supra-segmentals as the purpose was to check segmental elements. According to the results, it was indicated that the most problematic sounds for Turkish EFL preservice teachers were listed as /ə/, diphthongs, /æ/, /w/, /r/, /n/, / / / .

The abovementioned studies indicate that the issues of sounds and sound patterns of English among language learners have long been a question in EFL settings. A considerable amount of literature focuses on the problematic sounds of English among learners of English and the advantages and disadvantages of approaches to pronunciation training. However, the review of the literature reveals that there seems to be a gap regarding the teaching of pronunciation in extensive reading classes (labeled as reading circle classes in this study). Thus, focusing particularly on segmental level pronunciation problems of non-native speakers of English, this study aims to explore whether explicit instruction of pronunciation in L2 setting has an advantage over implicit pronunciation training in extensive reading circle classes.

1. Does the type of instruction in extensive reading classes influence the accurate pronunciation rate of English words at segmental level among Turkish EFL learners?

2. If the type of instruction has an effect on the accurate pronunciation rate of English words among Turkish EFL learners, is there a significant difference between the 
experimental group who received explicit instruction and the control group who received implicit instruction?

\section{Methods}

\subsection{Participants}

The participants of the study were two groups of B1-level Intensive English Program (IEP) students of a university in Turkey. In this program, the students are placed according to the results of a placement test given at the beginning of the academic year and are expected to finish the program at B2 level before they can start their education in their pre-assigned departments. During their education, their progress is checked through both continuous assessment including weekly quizzes, presentations and portfolio, and an exit test given at the end of eight-week periods. Depending on their performance, they may pass to the next level or repeat the level they have studied. Within the levels, the students are again placed according to their score rankings from the highest to the lowest and grouped accordingly. In order to make sure that the groups were comparable in this study, two successive classes (B1C1 and B1-C2) were selected. Selection of the groups was based on convenience sampling as the researcher was assigned to do reading circles with both groups.

This research was designed as quasi-experimental, and one class was assigned to be the control group while the other class was assigned to be the experimental group. There were 22 students in the experimental group and 17 students in the control group. Even though their placement test and level test scores showed that the groups did not differ significantly, the homogeneity of the experiment group ( $\mathrm{N}=22, \mathrm{M}=65.99)$ and the control group $(\mathrm{N}=17 \mathrm{M}=67.95)$ was also proved through Levene's test of homogeneity run for the pronunciation pre-test scores of the students $(F=0,02$; $\mathrm{p}=0,88)$.

\subsection{Data collection instrument and procedures}

At B1 level, the students were expected to read two simplified readers for extensive reading purposes. While the first book chosen was a between-levels (A2+) book, the second book was a B1 level book. The first book was short, and the students were expected to finish it during the first two weeks while the remaining six weeks were spent on the second book. For the purposes of this study, the second book was converted into a text file, and the word list and their frequency counts were identified using AntConc version 3.5.8 (Anthony, 2019). There were 1195 types and 13149 tokens in total. Taking Nation and Meara's (2010) suggestion for the amount of exposure to vocabulary items for incidental learning to take place - even though only pronunciation is targeted in this study, 29 words which fell between the frequency range of 6 and 15 tokens were selected as the focus word list for this study.

At the beginning of the eight-week period, a meeting was organized with the students to get their consent to record their voice and use them for research purposes. 
This was followed by asking the students in both groups to pronounce the 29 words on the list individually. As the focus of the study was more on the segmental level, the words were not contextualized. While the students were pronouncing the words one by one, their voices were recorded through a microphone attached to a computer. After finishing the eight-week period in which both groups studied the abovementioned two books, we waited for two extra weeks to repeat the same procedure for post-test purposes to observe whether the learners could retain what they had learned during the 8-week period.

\subsection{In-class activities}

As part of the IEP, two hours a week were allocated to extensive reading-related activities. These included reading circle activities based on weekly reading assignments from the designated graded readers. In these activities students were expected to share their reading circle role products with their group members. In addition, the learners were expected to use audio book which was available on the book CD. Hence, they were advised to follow the book through dramatized audio recordings featuring American native-speaker actors since it was believed that exposure would help learners improve their pronunciation. Thus, an implicit approach to pronunciation was preferred. In order to make sure that all students listened to the audio recordings, the teacher played the audio recording in the classroom, and the students followed the story from their books. Then the teacher chose students randomly to read aloud a specific part of the chapter. As long as they did not make fundamental pronunciation mistakes, they were not interrupted by the teacher. To make sure that everyone understood what was being read, the teacher made explanations or asked questions to spark a discussion related to the reading. When a book was finished, the students were encouraged to do the reading and vocabulary activities on the Multi-Rom pack containing interactive activities designed to reinforce key language skills at B1 level.

In this study, the procedure explained above was followed with the control group students. The same procedure was followed with the experimental group, and the only difference was the way the pronunciation was handled with the experimental group. When the students in the experimental group made a mistake while reading aloud, their pronunciation was corrected through modeling and repetition. In addition, teaching broad transcriptions of the words that the learners had problems with was an important part of the lesson. Furthermore, pronunciation games and competitions such as 'repeat until you find the correct pronunciation' or 'find your rival's pronunciation mistakes' were designed and played to increase the students' awareness regarding the correct pronunciation of the words in their readings.

Even though the words for the pre and post-tests were chosen from the second book, the in-class activities mentioned above were done also with the first book. In order to avoid focusing only on the pronunciation of the words that the students encountered in the pre and post-tests, and to observe whether explicit teaching of pronunciation 
raised awareness of better pronunciation in general among the learners, we extended these in-class activities to every extensive reading session of the eight-week period. That is, while the pre and the post-tests measured the pronunciation of 29 words selected from the second book, in-class activities for pronunciation were not limited to those words only but any word that the students did not pronounce correctly during the eight-week period.

\subsection{Data analysis procedure}

After the list of words to be included in the pre and post-tests was determined, their possible correct pronunciations were phonetically transcribed using learner dictionaries by reputable publishers. Before the beginning of the eight-week period, the students were asked to read the word list individually, and their readings were recorded for pre-test purposes. The same procedure was repeated two weeks after the students finished the eight-week period for post-test purposes.

Depending on the standard pronunciation of the words retrieved from the dictionaries, the students' pronunciations of individual words were marked as 'correct' or 'incorrect'. While the correct pronunciation was assigned the value ' 1 ', ' 0 ' was assigned to the incorrect pronunciation. A decision was made to normalize the correct frequency counts per 100 words in order to convert frequencies into scores out of a hundred.

For reliability purposes, pre and post-test recordings of four students -two from the control and two from the experimental groups- were evaluated by the researcher and an outsider evaluator specialized in pronunciation training and phonetic transcription. After normalizing the correct frequency counts by the two evaluators, the scores were compared for reliability purposes. Pearson's $r$ correlation was run to find out how much the two researchers correlated in their evaluations of student pronunciation. The results showed that there was a strong correlation between the evaluations of the two evaluators at $\mathrm{p}<.01$ level $(r=.86)$ with an effect size of $R^{2}=.74$. Sources of the differences between the two evaluators were identified and negotiated for an agreement, and this was followed by the evaluation of all the recordings by the researcher. After the evaluation, the frequencies were normalized per 100 words, and the obtained scores were analyzed with SPSS 23 descriptive statistics, paired samples t-test and independent samples t-test. In addition, the sources and varieties of pronunciation problems and patterns of improvement/change were discussed with a qualitative approach.

\section{Results}

At the end of the ten-week period, the learners were given the post-test. Upon the completion of the data gathering process, the scores of both groups were compared to their pre-test scores. The comparisons of pre-test and post-test scores of each group were made through paired samples t-test to explore the level of change within the 
groups. Table 1 below illustrates the mean scores, standard deviations and number of the participants in both control and experimental groups.

Table 1. Mean scores of the control and experimental groups in pre-test and post-test

\begin{tabular}{llllll}
\hline & & Mean & N & Std. Deviation & Std. Error Mean \\
\hline Control group & pre-test & 67.95 & 17 & 13.40 & 3.25 \\
& post-test & 70.40 & 17 & 13.58 & 3.29 \\
Experimental & pre-test & 65.99 & 22 & 16.37 & 3.49 \\
group & post-test & 82.46 & 22 & 11.11 & 2.37 \\
\hline
\end{tabular}

As shown in Table 1, the change of the mean scores from the pre-test to post-test in the control group was $2.45 \%$ while a $16.47 \%$ difference was observed in the experimental group. Even though the descriptive statistics results indicated that the level of improvement among the participants in the control group was minor, a paired samples t-test was conducted to figure out whether the implicit pronunciation training had a significant effect on the pronunciation performances of the learners. The findings supported the descriptive results since a significant difference of the mean scores from pre-test to post-test was not observed at $\mathrm{p}<0.05$ level $(\mathrm{M}=-2.45$ (mean score difference), $\mathrm{sd}=7.69, \mathrm{df}=16, \mathrm{p}=0.21$ ) with the $95 \% \mathrm{CI}$ of the difference of $6.40,1.50$ in means ( $\mathrm{t}=-1.31)$. The same test was applied for the experimental group and it was found that the participants in this group had a significant progress in their pronunciation at $\mathrm{p}<0.05$ level $(\mathrm{M}=-16.47$ (mean score difference), $\mathrm{sd}=16.42, \mathrm{df}=21$, $\mathrm{p}=0.00)$ as the $95 \% \mathrm{CI}$ for the difference in means was $-23.75,-9.19(\mathrm{t}=-4.71)$.

Since the main focus of the current research was to explore whether the type of training has an impact on the pronunciation performances of the learners, the posttest results of the two groups were compared through independent samples t-test. Table 2 illustrates the independent samples t-test result of the post-test scores of the control and experimental groups.

Table 2. Independent samples t-test results of post-test scores of control and experimental groups

\begin{tabular}{|c|c|c|c|c|c|c|c|c|}
\hline \multirow[b]{3}{*}{ Equal variances } & \multicolumn{2}{|c|}{ Levene's Test } & \multicolumn{6}{|c|}{ t-test for equality of means } \\
\hline & \multirow[b]{2}{*}{$\mathrm{F}$} & \multirow[b]{2}{*}{ Sig. } & \multirow[b]{2}{*}{$\mathrm{t}$} & \multirow[b]{2}{*}{$\mathrm{df}$} & \multirow{2}{*}{$\begin{array}{l}\text { Sig. (2- } \\
\text { tailed) }\end{array}$} & \multirow[b]{2}{*}{ Mean difference } & \multicolumn{2}{|c|}{$\begin{array}{l}95 \% \text { confidence interval of } \\
\text { the difference }\end{array}$} \\
\hline & & & & & & & $\overline{\text { Lower }}$ & Upper \\
\hline assumed & 1.26 & .27 & 3.05 & 37 & .004 & 12.06 & 4.05 & 20.07 \\
\hline not assumed & & & 2.97 & 30.60 & .006 & 12.06 & 3.78 & 20.34 \\
\hline
\end{tabular}

As can be seen in Table 2, assumption of equal variances was verified through Levene's test for equality of variances since the significance level was higher than $0.05(\mathrm{p}=0.27)$. Hence, we used the test results concerning the equal variances assumed. The independent samples t-test, which was conducted to explore if the control group who received implicit pronunciation training and the experimental group who were trained through explicit pronunciation instruction in their extensive reading classes differed significantly on their productive post-test, depicted the statistically significant superiority of the explicit pronunciation instruction over the implicit one in extensive reading classes at $p>0.05$ level. For the test, $(C G M=70.40$, 
$\mathrm{sd}=13.58, \mathrm{~N}=17$; EG $\mathrm{M}=82.46, \mathrm{sd}=11.11, \mathrm{~N}=22$ ), the $95 \%$ confidence interval of the difference in means was 4.05, $20.07(\mathrm{t}=3.05, \mathrm{p}=0.004, \mathrm{df}=37)$. Thus, the null hypothesis indicating that type of pronunciation training does not have an effect on the performances of the learners has to be rejected and the effect size was large for the level of the difference across the groups (Cohen's $d=1.00$ ). In a nutshell, the comparisons of overall performances of the participants both within and across the groups revealed that teaching pronunciation explicitly is more advantageous than implicit pronunciation training.

Depending on the overall results, we explored the correct-incorrect pronunciation rates of each word in both groups regarding the learners' pre and post-test performances to figure out the source and extent of differences in each group from the pre-test to the post-test. Table 3 below illustrates the level of each word's change from the pre-test to the post-test in each group.

As shown in Table 3, out of 29 words, the control group increased the appropriate pronunciation range of 14 words, while the correct pronunciation of 24 words in the experimental group went up in the post-test. The range of the positive change from the pre-test to post-test in the control group was between $17.70 \%$ and $5.90 \%$ whereas the level of increase in the experimental group was distributed in the range of $60.70 \%$ to $4.50 \%$. The result demonstrates that in addition to the overall results, the number of correct pronunciation of the individual words in the experimental group outnumbered the ones in the other group. However, the other side of the coin revealed that the frequency of correct pronunciation of six words decreased in the control group in the post-test and the level of decrease was between $-5.80 \%$ and $-23.50 \%$. However, the frequency of correct pronunciation of four words decreased in the experimental group within the range of $-4.60 \%$ to $-4.50 \%$. It is interesting to note that the correct pronunciation of 14 words in the control group and two words in the experimental group did not change from the pre-test to post-test (see Appendices A and B). It could be stated that the participants in the experimental group seem to correct most of their mispronunciations in the post-test. Nonetheless, the participants in the control group had to struggle with the similar pronunciation problems that they had in their pretest. It is clear that explicit pronunciation training in extensive reading classes positively affect the pronunciation performances of the learners while implicit training does not have a paramount effect on the learners' performances.

The most paramount positive change in the control group was observed in the pronunciation of 'answer', 'dangerous' and 'found' while 'young' was the most frequently mispronounced word in the post-test. Contrarily, the most notable increase in the correct pronunciation was observed in the production of 'packages' in the experimental group whereas the mispronunciation of 'believe' had the highest frequency in the post-test. It should be noted that the performance of the learners in the control group regarding the pronunciation of 'packages' was not satisfying since only three pupils were able to pronounce the word correctly in the post-test. This was due to the fact that the majority of the learners in the control group was not aware of 
the appropriate pronunciation of plural $-\mathrm{s}$ [1z] used in the word (inappropriate pronunciation e.g. /pækıdzz/ and /pækıdzs/).

Table 3. Frequency counts and percentages of correctly pronounced words in both groups

\begin{tabular}{|c|c|c|c|c|c|c|c|c|c|c|c|c|}
\hline \multirow{3}{*}{ WORD } & \multicolumn{6}{|c|}{ CONTROL GROUP } & \multicolumn{6}{|c|}{ EXPERIMENTAL GROUP } \\
\hline & \multicolumn{2}{|c|}{ Pre-Test } & \multicolumn{2}{|c|}{ Post-Test } & \multicolumn{2}{|c|}{ Difference } & \multicolumn{2}{|c|}{ Pre-Test } & \multicolumn{2}{|c|}{ Post-Test } & \multicolumn{2}{|c|}{ Difference } \\
\hline & $\mathrm{N}$ & $\%$ & $\mathrm{~N}$ & $\%$ & $\mathrm{~N}$ & $\%$ & $\mathrm{~N}$ & $\%$ & $\mathrm{~N}$ & $\%$ & $\mathrm{~N}$ & $\%$ \\
\hline Vacation & 6 & 35.30 & 7 & 41.20 & 1 & 5.90 & 3 & 13.60 & 13 & 59.10 & 10 & 45.50 \\
\hline Dangerous & 11 & 64.70 & 14 & 82.40 & 3 & 17.70 & 16 & 72.70 & 18 & 81.80 & 2 & 9.10 \\
\hline Both & 12 & 70.60 & 13 & 76.50 & 1 & 5.90 & 17 & 77.30 & 22 & 100.00 & 5 & 22.70 \\
\hline Worried & 16 & 94.10 & 16 & 94.10 & 0 & 0.00 & 22 & 100.00 & 21 & 95.50 & -1 & -4.50 \\
\hline Talked & 12 & 70.60 & 12 & 70.60 & 0 & 0.00 & 13 & 59.10 & 19 & 86.40 & 6 & 27.30 \\
\hline Arrived & 15 & 88.20 & 16 & 94.10 & 1 & 5.90 & 20 & 90.90 & 19 & 86.40 & -1 & -4.50 \\
\hline Quietly & 13 & 76.50 & 13 & 76.50 & 0 & 0.00 & 18 & 81.80 & 20 & 90.90 & 2 & 9.10 \\
\hline Answer & 3 & 17.60 & 6 & 35.30 & 3 & 17.70 & 7 & 31.80 & 20 & 90.90 & 13 & 59.10 \\
\hline Person & 16 & 94.10 & 17 & 100.00 & 1 & 5.90 & 18 & 81.80 & 20 & 90.90 & 2 & 9.10 \\
\hline Watched & 13 & 76.50 & 14 & 82.40 & 1 & 5.90 & 15 & 68.20 & 16 & 72.70 & 1 & 4.50 \\
\hline Minute & 15 & 88.20 & 13 & 76.50 & -2 & -11.70 & 20 & 90.90 & 19 & 86.40 & -1 & -4.50 \\
\hline Laughed & 5 & 29.40 & 5 & 29.40 & 0 & 0.00 & 7 & 31.80 & 16 & 72.70 & 9 & 40.90 \\
\hline Angrily & 15 & 88.20 & 14 & 82.40 & -1 & -5.80 & 21 & 95.50 & 22 & 100.00 & 1 & 4.50 \\
\hline Believe & 13 & 76.50 & 13 & 76.50 & 0 & 0.00 & 17 & 77.30 & 16 & 72.70 & -1 & -4.60 \\
\hline Perhaps & 6 & 35.30 & 3 & 17.60 & -3 & -17.70 & 3 & 13.60 & 12 & 54.50 & 9 & 40.90 \\
\hline Terrible & 16 & 94.10 & 16 & 94.10 & 0 & 0.00 & 21 & 95.50 & 22 & 100.00 & 1 & 4.50 \\
\hline Thinking & 3 & 17.60 & 5 & 29.40 & 2 & 11.80 & 3 & 13.60 & 10 & 45.50 & 7 & 31.90 \\
\hline Different & 17 & 100.00 & 17 & 100.00 & 0 & 0.00 & 21 & 95.50 & 22 & 100.00 & 1 & 4.50 \\
\hline Marina & 3 & 17.60 & 5 & 29.40 & 2 & 11.80 & 10 & 45.50 & 10 & 45.50 & 0 & 0.00 \\
\hline Scared & 11 & 64.70 & 13 & 76.50 & 2 & 11.80 & 13 & 59.10 & 17 & 77.30 & 4 & 18.20 \\
\hline Suddenly & 16 & 94.10 & 16 & 94.10 & 0 & 0.00 & 19 & 86.40 & 21 & 95.50 & 2 & 9.10 \\
\hline Kids & 17 & 100.00 & 16 & 94.10 & -1 & -5.90 & 20 & 90.90 & 22 & 100.00 & 2 & 9.10 \\
\hline Our & 16 & 94.10 & 17 & 100.00 & 1 & 5.90 & 19 & 86.40 & 21 & 95.50 & 2 & 9.10 \\
\hline Young & 16 & 94.10 & 12 & 70.60 & -4 & -23.50 & 19 & 86.40 & 19 & 86.40 & 0 & 0.00 \\
\hline Tower & 15 & 88.20 & 14 & 82.40 & -1 & -5.80 & 16 & 72.70 & 20 & 90.90 & 4 & 18.20 \\
\hline Live (v) & 17 & 100.00 & 17 & 100.00 & 0 & 0.00 & 20 & 90.90 & 21 & 95.50 & 1 & 4.60 \\
\hline Found & 10 & 58.80 & 13 & 76.50 & 3 & 17.70 & 14 & 63.60 & 17 & 77.30 & 3 & 13.70 \\
\hline Packages & 1 & 5.90 & 3 & 17.60 & 2 & 11.70 & 1 & 4.50 & 15 & 68.20 & 14 & 63.70 \\
\hline Beautiful & 6 & 35.30 & 7 & 41.20 & 1 & 5.90 & 8 & 36.40 & 16 & 72.70 & 8 & 36.30 \\
\hline
\end{tabular}

Regarding the other problematic sounds among the learners participated in the current study, it was found that the consonant sounds of $/ \theta /, / \mathrm{w} /, / \mathrm{y} /, / \mathrm{j} /$, and vowel sounds of $/ \mathrm{N} /, / \mathrm{el} /, / \mathrm{\partial} /, / \mathrm{l} /, / æ /$ were mispronounced with varying frequencies which approved the findings of Demirezen (2007), Hişmanoğlu (2007) and Bardakçı (2015). $/ \theta /$ sound in the cases of / $\theta \mathrm{m} \mathrm{mm} /$ and $/ \mathrm{bov} \theta /$ were pronounced as /tinkı/ and /bout/ and /bot/ while /w/ in /kwaıtli/ was produced as /'kvaıtli/ and /'kvətli/. In addition, /y/ in 


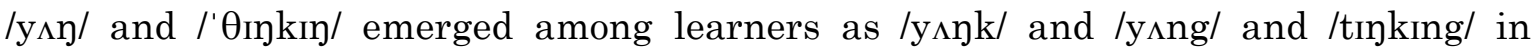
various cases. Regarding the /j/ sound in /'bju:təfl/, learners mispronounced the phoneme as /'bi:tofl/, /bi:tufl/ or /bi:tuful/. As for the central vowels /s/ and /a/ in /'wurid/, /'demdzərəs/ and /'ænsər/, they were pronounced as /worid/, /'dendzrus/, /'d $\Lambda$ ngerus/, /'deindzrus/, /'d $\Lambda$ dzros/ or /'dendzorus/ and /'ænswer/. In addition to the mispronunciation of /a/ in /'demdzərəs/, we observed that learners mispronounced the diphthong /ei/ in that word. The pronunciation of /1/ and /æ/ as front vowels in / minit/ and /'ænsər/ and /læft/ were observed to be used as /'mmot/ and /answər/ and /laft/ or /lavghıd/. Moreover, the phoneme /1/ in /'pækıdzız/ was not produced by some of the learners as they pronounced the word as /'pakıdzz/ or /'pekerdzz/. Finally, the functional morpheme of -ed was frequently mispronounced in both groups. To illustrate, /tokt/, /a'raivd/, /wotft/, /læft/ and /skerd/ were pronounced as /talkıd/, /a'raivid/, /wotfId/, /lavghıd/ and /skerıd/.

\section{Discussion and conclusion}

Assessing the contribution of explicit pronunciation training consisting of the activities mentioned in the methods section to the development of correct pronunciation for Turkish learners of English was the primary purpose of the current study. Depending on the analyses of the pre- and post-tests, it could be tenable to claim that the use of the pronunciation techniques suggested for this study has positive effects on the pronunciation performances of the learners. This study provides indisputable evidence to approve the key claims stated by Derwing and Munro (2005), Couper (2011), Saito (2011) and Khanbeiki and Abdolmanafi-Rokni (2015) regarding the importance of explicit pronunciation training in EFL settings. Particularly, Derwing and Munro (2005) revealed that teachers of English need to draw the learners' attention to the significance of pronunciation for mutual intelligibility and to help them improve their pronunciation performances through explicit instruction. In addition, similar to our findings Derwing, Munro, and Wiebe (1998) highlight the value of segmental explicit training as they claim that "in the case of a communication breakdown caused by a mispronunciation, a student who has received segmental training might be able to focus on the mispronounced form in a self-repetition" ( $p$. 407).

Furthermore, it is highly advised that explicit pronunciation training in extensive reading classes could help learners improve their pronunciation competence along with their lexical competence and they could improve their self-confidence regarding the use of TL as a natural consequence of improving their intelligibility thanks to correct pronunciation of the segmental units. It is also evident that learners could become competent users of the TL if the teaching techniques focus on problematic phonemes of the learners as well as the other components of the language.

As reported by Çakır (2012), learners might mispronounce English words due to their previous education and the majority of the incorrect learnings causes fossilization in learner language. It seems essential to find out problematic sounds for 
them and develop teaching techniques and materials that could guide them to remedy fossilized mispronunciation of the sounds in the TL. According to Demirezen (2003, 2005, 2010) and Hişmanoğlu (2007), fossilized sounds could be corrected through the Audio-articulation Method which includes pronunciation activities created through corpora. Similar to the suggestions of Demirezen and Hişmanoğlu, one of the purposes of implementing explicit pronunciation training particularly in extensive reading classes in this study was to raise learner's awareness regarding the appropriate pronunciation of English words through in-context activities with the help of the situational context created in the graded readers. Furthermore, we also bore the suggestions of Derwing, Munro, and Wiebe (1998) in mind and taught correct pronunciation of segmental units by taking the most frequently repeated words in the graded readers out of the context to make sure that learners were able to focus on the correct pronunciation of the words. According to the results obtained in this study, it could justifiably be claimed that language instructors need to teach pronunciation explicitly and pronunciation training should cover both context-related activities and segmental pronunciation teaching isolated from the context since learners instinctively focus on overall comprehension in the course of language learning rather than other components of language such as pronunciation, syntax or semantics (VanPattern, 1996). Similar to Schmidt (1990), it could be suggested that learners need to recognize and feel the importance of the information to be able to convert the input into intake which impacts the linguistic system of the learners.

Regarding the perception of the pronunciation training by language instructors, it could be stated that the study of pronunciation needs to be encouraged since teachers of English are generally left to rely on their own intuitions and majority of the language instructors do not want to teach pronunciation since they do not know how to teach it (Derwing \& Munro, 2005). We believe that in addition to the previous studies of pronunciation training in EFL classes, the teaching techniques introduced in the methods section and the results drawn from the analyses of the pre and posttests attached great importance to explicit pronunciation training in extensive reading classes.

Put in a nutshell, this study recommends a new perspective to pronunciation training in the sense that it focuses on enhancing appropriate pronunciation performance of the learners through various explicit pronunciation training activities in extensive reading classes. Nevertheless, we feel the necessity of expressing that the study has a variety of limitations. Firstly, all the participants of the study were from the same university in Turkey and thus the results might not be generalized to the whole Turkish EFL learners learning English in Turkey. Additionally, since the backbone of the study was to explore whether the type of pronunciation training had an effect on the learners' pronunciation performances, we had to work with intact groups with similar proficiency levels. For this reason, the participants may not be representative of all the $\mathrm{B} 1$ level students. However, the results of the study shed light to the need and importance of explicit pronunciation training in extensive reading classes in intensive language programs. A further study might explore the 
long-term effects of explicit pronunciation training on the pronunciation performances of different words that were not covered in this study to figure out whether learners could transfer their knowledge to the appropriate pronunciation of other English words.

\section{References}

Anthony, L. (2019). AntConc (Version 3.5.8) [Computer Software]. Tokyo, Japan: Waseda University. Available from https://www.laurenceanthony.net/software

Bardakci, M. (2015). Turkish EFL pre-service teachers' pronunciation problems. Educational Research and Reviews, 10(16), 2370-2378. doi:10.5897/ERR2015.2396

Brinton, D. M. (2017). Pronunciation. In E. Hinkel (Ed.), Handbook of research in second language teaching and learning (Vol. 3, pp. 257-270). New York, NY: Routledge.

Çakır, İ. (2012). Promoting correct pronunciation through supported audio materials for EFL learners. Energy Education Science and Technology Part B: Social and Educational Studies, 4(3), 1801-1812.

Celce-Murcia, M., Brinton, D. M., \& Goodwin, J. M. (1996). Teaching pronunciation: A reference for teachers of English to speakers of other languages. New York: Cambridge University Press.

Chan, R., \& Leung, J. (2014). Implicit learning of L2 word stress regularities. Second Language Research, 30(4), 463-483. https://doi.org/10.1177/0267658313510169

Couper, G. (2011). What makes pronunciation teaching work? Testing for the effect of two variables: socially constructed metalanguage and critical listening. Language Awareness, 20(3), 159-182. https://doi.org/10.1080/09658416.2011.570347

Darcy, I. (2018). Powerful and effective pronunciation instruction: How can we achieve it? The CATESOL Journal, 30(1), 13- 45.

Retrieved from https://files.eric.ed.gov/fulltext/EJ1174218.pdf

Demirezen, M. (2003). Turkish learners' pronunciation problems caused by the English phoneme of THETA. Tömer Language Journal, 120, 57-71.

Demirezen, M. (2005). The /o/ and /ow/ contrast: Curing a fossilized pronunciation error of Turkish teacher trainees of the English language. Çankaya University Journal of Arts and Sciences, 1(3), 71-84.

Retrieved from http://dergipark.ulakbim.gov.tr/cankujas/article/view/5000004387

Demirezen, M. (2010). The principles and applications of the audio-lingual pronunciation rehabilitation model in foreign language teacher education. Journal of Language and Linguistic Studies, 6(2), 127-147.

Retrieved from https://www.jlls.org/index.php/jlls/article/view/99

Derwing, T. M., \& Munro, M. J. (2005). Second language accent and pronunciation teaching: A research-based approach. TESOL Quarterly, 39(3), 379-397.

https://doi.org/10.2307/3588486

Derwing, T. M., \& Munro, M. J. (2008). Segmental acquisition in adult ESL learners: A Longitudinal study of vowel production. Language Learning, 58(3), 479-502. https://doi.org/10.1111/j.1467-9922.2008.00448.x

Derwing, T. M., \& Rossiter, M. J. (2002). ESL learners' perceptions of their pronunciation needs and strategies. System, 30(2), 155-166.

http://dx.doi.org/10.1016/S0346-251X(02)00012-X 
Derwing, T. M., Munro, M. J., \& Wiebe, G. (1998). Evidence in favor of a broad framework for pronunciation instruction. Language Learning, 48(3), 393-410. https://doi.org/10.1111/0023-8333.00047

Flege, J. E., Yeni-Komshian, G. H., \& Liu, S. (1999). Age constraints on second-language acquisition. Journal of Memory \& Language, 41(1), 78-104. https://doi.org/10.1006/jmla.1999.2638

Fraser, H. (1999). ESL pronunciation teaching: Could it be more effective? Australian Language Matters, 7(4), 7-8.

Fraser, H. (2000). Coordinating improvements in pronunciation teaching for adult learners of English as a second language. Canberra, Australia: Department of Education, Training and Youth Affairs.

Fraser, H. (2006). Helping teachers help students with pronunciation: A cognitive approach. Prospect: A Journal of Australian TESOL, 21(1), 80-96. Retrieved from http://hdl.handle.net/1959.14/329794

Gattegno, C. (1963). Teaching foreign languages in schools: The silent way. Reading: Educational Explorers.

Pourhosein Gilakjani, A. (2012). A Study of factors affecting EFL Learners' English pronunciation learning and the strategies for instruction. International Journal of Humanities and Social Science, 2(3), 119-128.

Hişmanoğlu, M. (2007). [0:] and [ov] contrast as fossilized pronunciation error of Turkish learners of English and solutions to the problem. Journal of Language and Linguistic Studies, 3(1), 98-116.

Retrieved from https://www.jlls.org/index.php/jlls/article/view/41/41

Hismanoglu, M. (2006). Current perspectives on pronunciation learning and teaching. Journal of Language and Linguistic Studies, 2(1), 101-110.

Retrieved from https://www.jlls.org/index.php/jlls/article/view/26

Hymes, D. H. (1972). On communicative competence. In J. B. Pride \& J. Holmes (Eds.), Sociolinguistics: Selected readings (pp. 269-293). Baltimore, MD: Penguin.

Jenkins, J. (2000). The phonology of English as an international language: New models, new norms, new goals. Oxford: Oxford University Press.

Jenkins, J. (2007). English as a lingua franca: Attitude and identity. Oxford: Oxford University Press.

Khanbeiki, R., \& Abdolmanafi-Rokni, S. J. (2015). The effect of explicit vs. implicit instruction on the learnability of English consonant clusters by Iranian learners of English. Advances in Language and Literary Studies, 6(2), 103-112. Retrieved from https://files.eric.ed.gov/fulltext/EJ1128324.pdf

Kissling, E. M. (2013). Teaching pronunciation: Is explicit phonetics instruction beneficial for FL learners? The Modern Language Journal, 97(3), 720-744. https://doi.org/10.1111/j.1540-4781.2013.12029.x

Larsen-Freeman, D., \& Anderson, M. (2011). Techniques \& principles in language teaching. Oxford: Oxford University Press.

Lightbown, P. M., \& Spada, N. (2013). How languages are learned. London: Oxford University Press.

Morley, J. (1991). The pronunciation component in teaching English to speakers of other languages. TESOL Quarterly, 25(3), 481-520. https://doi.org/10.2307/3586981

Nation, I. S. P., \& Meara, P. (2010). Vocabulary. In N. Schmitt (Ed.), An introduction to applied linguistics (Second Edition, pp. 34-52). London, UK: Edward Arnold. 
Papachristou, V. (2011). Explicit vs. implicit pronunciation teaching to Greek children: The case of the acquisition of English vowels. Selected papers on theoretical and applied linguistic, 19(1), 371-381.

Preston, D. R. (1981). The ethnography of TESOL. TESOL Quarterly, 15(2), 105-116. http://dx.doi.org/10.2307/3586402

Richards, J. C., \& Rodgers, T. S. (2006). Approaches and methods in language teaching. Cambridge: Cambridge University Press.

Saito, K. (2011). Identifying problematic segmental features to acquire comprehensible pronunciation in EFL settings: The case of Japanese learners of English. RELC Journal, 42(3), 363-378. https://doi.org/10.1177/0033688211420275

Saka, Z. (2015). The effectiveness of audiobooks on pronunciation skills of EFL learners at different proficiency levels (Unpublished Master's Thesis). İhsan Doğramacı Bilkent University, Ankara.

Schmidt, R. (1990). The role of consciousness in second language learning. Applied Linguistics, 11(2), 120-158. https://doi.org/10.1093/applin/11.2.129

Seidlhofer, B. (2005). English as a lingua franca. ELT Journal, 59(4), 339-341. http://dx.doi.org/10.1093/elt/cci064

Silveria, R. (2011). Pronunciation instruction and syllabic-pattern discrimination. DELTA, 27(1), 21-36. http://dx.doi.org/10.1590/S0102-44502011000100002

Sturm, J. 2013. Explicit phonetics Instruction in L2 French: a Global Analysis of Improvement. System, 41(3), 654-662. https://doi.org/10.1016/j.system.2013.07.015

Underhill, A. (2005). Sound foundations: Learning and teaching pronunciation. Oxford: Macmillan Publishers.

Türker, H. (2010). Common mistakes of Turkish secondary students in pronunciation of English words and possible solutions (Unpublished master's thesis). Çanakkale On Sekiz Mart University, Çanakkale.

VanPattern, B. (1996). Input processing and grammar instruction: Theory and research. Norwood, NJ: Ablex.

Venkatagiri, H. S., \& Levis, J. M. (2007). Phonological awareness and speech comprehensibility: An exploratory study. Language Awareness, 16(4), 263-277. https://doi.org/10.2167/la417.0

Walker, R. (2010). Teaching the pronunciation of English as a lingua franca. Oxford: Oxford University Press.

Zhang F., \& Yin, P. (2009). A study of pronunciation problems of English learners in China. Asian Social Science, 5(6), 141-146. doi:10.5539/ass.v5n6p141 
Appendix A. Control group: Word-based change from pre- to post-test

\begin{tabular}{|c|c|c|c|c|c|c|c|c|}
\hline \multirow[t]{2}{*}{ WORD } & \multicolumn{2}{|c|}{$\begin{array}{l}\text { CHANGE FROM } \\
\text { INCORRECT TO } \\
\text { CORRECT }\end{array}$} & \multicolumn{2}{|c|}{$\begin{array}{l}\text { NO CHANGE FROM } \\
\text { INCORRECT TO } \\
\text { INCORRECT }\end{array}$} & \multicolumn{2}{|c|}{$\begin{array}{l}\text { CHANGE FROM } \\
\text { CORRECT TO } \\
\text { INCORRECT }\end{array}$} & \multicolumn{2}{|c|}{$\begin{array}{l}\text { NO CHANGE FROM } \\
\text { CORRECT TO } \\
\text { CORRECT }\end{array}$} \\
\hline & $\mathrm{N}$ & $\%$ & $\mathrm{~N}$ & $\%$ & $\mathrm{~N}$ & $\%$ & $\mathrm{~N}$ & $\%$ \\
\hline Vacation & 3 & 17.6 & 8 & 47.1 & 2 & 11.8 & 4 & 23.5 \\
\hline Dangerous & 2 & 11.8 & 4 & 23.5 & 0 & 0.0 & 11 & 64.7 \\
\hline Both & 2 & 11.8 & 3 & 17.6 & 1 & 5.9 & 11 & 64.7 \\
\hline Worried & 0 & 0.0 & 1 & 5.9 & 0 & 0.0 & 16 & 94.1 \\
\hline Talked & 0 & 0.0 & 5 & 29.4 & 0 & 0.0 & 12 & 70.6 \\
\hline Arrived & 1 & 5.9 & 1 & 5.9 & 0 & 0.0 & 15 & 88.2 \\
\hline Quietly & 2 & 11.8 & 2 & 11.8 & 2 & 11.8 & 11 & 64.7 \\
\hline Answer & 4 & 23.5 & 10 & 58.8 & 0 & 0.0 & 3 & 17.6 \\
\hline Person & 0 & 0.0 & 0 & 0.0 & 1 & 5.9 & 16 & 94.1 \\
\hline Watched & 2 & 11.8 & 0 & 0.0 & 1 & 5.9 & 12 & 70.6 \\
\hline Minute & 1 & 5.9 & 1 & 5.9 & 3 & 17.6 & 12 & 70.6 \\
\hline Laughed & 0 & 0.0 & 12 & 70.6 & 0 & 0.0 & 5 & 29.4 \\
\hline Angrily & 1 & 5.9 & 1 & 5.9 & 2 & 11.8 & 13 & 76.5 \\
\hline Believe & 1 & 5.9 & 3 & 17.6 & 1 & 5.9 & 12 & 70.6 \\
\hline Perhaps & 1 & 5.9 & 10 & 58.8 & 4 & 23.5 & 2 & 11.8 \\
\hline Terrible & 1 & 5.9 & & 0.0 & 1 & 5.9 & 15 & 88.2 \\
\hline Thinking & 3 & 17.6 & 11 & 64.7 & 1 & 5.9 & 2 & 11.8 \\
\hline Different & 0 & 0.0 & 0 & 0.0 & 0 & 0.0 & 17 & 100.0 \\
\hline Marina & 3 & 17.6 & 11 & 64.7 & 1 & 5.9 & 2 & 11.8 \\
\hline Scared & 3 & 17.6 & 3 & 17.6 & 1 & 5.9 & 10 & 58.8 \\
\hline Suddenly & 1 & 5.9 & 0 & 0.0 & 0 & 0.0 & 16 & 94.1 \\
\hline Kids & & 0.0 & & 0.0 & 1 & 5.9 & 16 & 94.1 \\
\hline Our & & 0.0 & 1 & 5.9 & & 0.0 & 16 & 94.1 \\
\hline Young & 2 & 11.8 & & 0.0 & 4 & 23.5 & 11 & 64.7 \\
\hline Tower & & 0.0 & 2 & 11.8 & 1 & 5.9 & 14 & 82.4 \\
\hline Live (v) & & 0.0 & & 0.0 & & 0.0 & 17 & 100.0 \\
\hline Found & 4 & 23.5 & 3 & 17.6 & 1 & 5.9 & 9 & 52.9 \\
\hline Packages & 3 & 17.6 & 13 & 76.5 & 1 & 5.9 & & 0.0 \\
\hline Beautiful & 2 & 11.8 & 9 & 52.9 & 1 & 5.9 & 5 & 29.4 \\
\hline TOTAL & 42 & 8.5 & 114 & 23.1 & 30 & 6.1 & 305 & 61.9 \\
\hline
\end{tabular}


Appendix B. Experimental group: Word-based change from pre- to post-test

\begin{tabular}{|c|c|c|c|c|c|c|c|c|}
\hline \multirow[t]{2}{*}{ WORD } & \multicolumn{2}{|c|}{$\begin{array}{l}\text { CHANGE FROM } \\
\text { INCORRECT TO } \\
\text { CORRECT }\end{array}$} & \multicolumn{2}{|c|}{$\begin{array}{l}\text { NO CHANGE FROM } \\
\text { INCORRECT TO } \\
\text { INCORRECT }\end{array}$} & \multicolumn{2}{|c|}{$\begin{array}{l}\text { CHANGE FROM } \\
\text { CORRECT TO } \\
\text { INCORRECT }\end{array}$} & \multicolumn{2}{|c|}{$\begin{array}{l}\text { NO CHANGE FROM } \\
\text { CORRECT TO } \\
\text { CORRECT }\end{array}$} \\
\hline & $\mathrm{N}$ & $\%$ & $\mathrm{~N}$ & $\%$ & $\mathrm{~N}$ & $\%$ & $\mathrm{~N}$ & $\%$ \\
\hline Vacation & 11 & 50.00 & 8 & 36.36 & 1 & 4.55 & 2 & 9.09 \\
\hline Dangerous & 2 & 9.09 & 4 & 18.18 & 0 & 0.00 & 16 & 72.73 \\
\hline Both & 5 & 22.73 & 0 & 0 & 0 & 0.00 & 17 & 77.27 \\
\hline Worried & 0 & 0.00 & 0 & 0 & 1 & 4.55 & 21 & 95.45 \\
\hline Talked & 6 & 27.27 & 3 & 13.64 & 0 & 0.00 & 13 & 59.09 \\
\hline Arrived & 0 & 0.00 & 2 & 9.09 & 1 & 4.55 & 19 & 86.36 \\
\hline Quietly & 3 & 13.64 & 1 & 4.55 & 1 & 4.55 & 17 & 77.27 \\
\hline Answer & 14 & 63.64 & 1 & 4.55 & 1 & 4.55 & 6 & 27.27 \\
\hline Person & 3 & 13.64 & 1 & 4.55 & 1 & 4.55 & 17 & 77.27 \\
\hline Watched & 4 & 18.18 & 3 & 13.64 & 3 & 13.64 & 12 & 54.55 \\
\hline Minute & 1 & 4.55 & 1 & 4.55 & 2 & 9.09 & 18 & 81.82 \\
\hline Laughed & 11 & 50.00 & 4 & 18.18 & 2 & 9.09 & 5 & 22.73 \\
\hline Angrily & 1 & 4.55 & 0 & 0 & 0 & 0.00 & 21 & 95.45 \\
\hline Believe & 1 & 4.55 & 4 & 18.18 & 2 & 9.09 & 15 & 68.18 \\
\hline Perhaps & 10 & 45.45 & 9 & 40.91 & 1 & 4.55 & 2 & 9.09 \\
\hline Terrible & 1 & 4.55 & 0 & 0 & 0 & 0.00 & 21 & 95.45 \\
\hline Thinking & 7 & 31.82 & 12 & 54.55 & 0 & 0.00 & 3 & 13.64 \\
\hline Different & 1 & 4.55 & 0 & 0 & 0 & 0.00 & 21 & 95.45 \\
\hline Marina & 5 & 22.73 & 7 & 31.82 & 5 & 22.73 & 5 & 22.73 \\
\hline Scared & 5 & 22.73 & 4 & 18.18 & 1 & 4.55 & 12 & 54.55 \\
\hline Suddenly & 2 & 9.09 & 1 & 4.55 & 0 & 0.00 & 19 & 86.36 \\
\hline Kids & 2 & 9.09 & 0 & 0 & 0 & 0.00 & 20 & 90.91 \\
\hline Our & 2 & 9.09 & 1 & 4.55 & 0 & 0.00 & 19 & 86.36 \\
\hline Young & 2 & 9.09 & 1 & 4.55 & 2 & 9.09 & 17 & 77.27 \\
\hline Tower & 4 & 18.18 & 2 & 9.09 & 0 & 0.00 & 16 & 72.73 \\
\hline Live (v) & 2 & 9.09 & 0 & 0 & 1 & 4.55 & 19 & 86.36 \\
\hline Found & 3 & 13.64 & 5 & 22.73 & 0 & 0.00 & 14 & 63.64 \\
\hline Packages & 15 & 68.18 & 6 & 27.27 & 1 & 4.55 & 0 & 0.00 \\
\hline Beautiful & 9 & 40.91 & 5 & 22.73 & 1 & 4.55 & 7 & 31.82 \\
\hline TOTAL & 132 & 20.69 & 85 & 13.32 & 27 & 4.23 & 394 & 61.76 \\
\hline
\end{tabular}

\section{Copyrights}

Copyright for this article is retained by the author(s), with first publication rights granted to the Journal. This is an open-access article distributed under the terms and conditions of the Creative Commons Attribution license (CC BY-NC-ND) (http://creativecommons.org/licenses/by-nc-nd/4.0/). 